\title{
Attitudes of University Members toward Accepting Students with Intellectual Disabilities: a systematic review study
}

Adel Alanazi ( $\sim$ asalanazi@ju.edu.sa )

Jouf University https://orcid.org/0000-0002-6378-1073

Ahmed Gadelmawla

Jouf University

\section{Research Article}

Keywords: attitude, university member, intellectual disability, accepting, systematic review

Posted Date: February 15th, 2021

DOl: https://doi.org/10.21203/rs.3.rs-179936/v1

License: (c) (1) This work is licensed under a Creative Commons Attribution 4.0 International License.

Read Full License 


\section{Abstract}

This aim of this article is to examine the attitudes of university members towards accepting students with intellectual disabilities (ID). To gather relevant data, 12 articles were selected from a wide range of online databases using a three-step search strategy. First, the search strategy and keywords were used to shortlist 31 articles. Second, inclusion-exclusion criteria were applied from which 23 articles were shortlisted. Finally, 12 articles were selected for the article based on the criteria for quality assessment. The examination of these selected articles revealed significant findings regarding the positive attitude of the university members towards students with ID. In 7 of the 12 articles, common findings included the positive attitude of teachers and university members towards accepting students with ID. Further, it can be concluded from the findings that universities have been adopting some key measures to improve the acceptance of students with ID. These measures include teacher training, the use of technology, effective lesson planning, curriculum design, and help to enhance student skills. However, substantial challenges remain in accepting students with ID and fulfilling their personal and educational requirements.

\section{Introduction}

Intellectual disability (ID) is a disability characterized by significant limitations both in intellectual functioning (reasoning, learning, problem solving) and in adaptive behaviour, which covers a range of everyday social and practical skills. Higher education is one of the most effective factors that can enhance an individual's potential. Post-secondary education for students with intellectual disabilities (ID) has emerged as a new frontier in higher education, focusing on improving their inclusion in both education and society (Argyropoulos, 2019). The implementation of various laws in Western countries has increased the number of opportunities for people with ID to participate actively in society, particularly in the United Kingdom and the United States (UNESDOC Digital Library, 2015). Within these countries, several new university programs have been developed to facilitate students with ID having access to effective and higher education. These higher education programs for students with ID have allowed universities to develop educational programs and curriculums in response to the desires and needs of both the parents and students (UNESDOC Digital Library, 2015).

However, the programs offered by the universities are non-degree or certificate programs. Therefore, despite participating in the curriculum, activities, and courses organised at the college, students with ID are only able to earn accreditation, not a degree. The wide variation in these university programs also suggests there were significant challenges in their development and implementation, highlighting the need for effective support from the university and its members (Gibbons et al., 2015). Previously, there has been substantial concern regarding these programs. These concerns include an absence of consistency in the programs, differences in the levels of social inclusion, the perspectives of teachers and students regarding the inclusion of students with ID, the challenges associated with the development and maintenance of such programs, and questions over sustainability (Gibbons et al., 2015). 
Previous studies in this context have also examined the challenges and issues encountered by students with ID while studying at the universities. However, an examination of the prevailing literature suggests that studies on the attitudes towards accepting students with ID displayed by university members (including administration, management, and the teaching staff) are sparse. Instead, focus is on the goals and requirements of universities for enrolling such students (Hayes and Bulat, 2017; Bouillet and Mirosevic, 2015). Additionally, there is a lack of research on accepting students with ID and their status in the various universities where programs are offered (Obiozor, Onu, and Ugwoegbu, 2010; Kabuta, 2014). Accordingly, the aim of this article is to address the research gap and gain relevant findings regarding how the current practices of universities can be improved to enhance the social inclusion of students with ID.

\section{Research Question}

This article aims to address the following question: 'What are the university members' attitudes toward accepting students with ID?'

\section{Method}

\section{Aim of the Study}

The aim of this study was to identify the steps and requirements for accepting young people with intellectual disabilities in universities by reviewing and analyzing a group of studies and discovering the opinions of teachers, university students and the university's administrative staff towards accepting people with intellectual disability and providing them with opportunities to be included into society

\section{Design and Setting of the Study}

This is a qualitative study whereby the data was gathered from secondary sources including academic journals and scholarly papers. These sources were examined through a systematic review to undertake a detailed assessment of the literature then further analysed through a quantitative analysis including graphs created through Microsoft Excel software.

Reviews conducted in academic research usually employ traditional methods and only focus on examining the findings regarding a specific area of research evidence and claims made by academics in the examined field. Further, the literature is only studied at face value (Boland, Cherry and Dickson, 2017). These limitations of conventional literature reviews can be overcome effectively through the application of a systematic review that incorporates explicit and credible methods of data collection, follows a standard format and sequence, and is accountable. These characteristics make it a reliable method to reach valid and authentic findings and motivate its application to evaluating the attitudes of university members towards accepting the students with ID (Gough, Thomas, and Oliver, 2017). 
When selecting the articles for the systematic review, three key stages were undertaken to shortlist the most credible and appropriate articles. First, a wide range of search terms and keywords were used to search for articles across various databases, which were then employed to conduct several trial searches across the electronic databases. The search terms and keywords applied for the collection of reliable and authentic papers were as follows: Practices of universities to adopt students with intellectual disabilities OR Students with intellectual disabilities OR Persons with intellectual disabilities OR Accepting students with intellectual disabilities OR University members OR Attitudes of teachers OR Attitudes of management and administration OR University goals and requirements for accepting students with intellectual disabilities OR Status of students with intellectual disabilities in UK universities OR Status of students with intellectual disabilities in USA universities. The following databases were used: Google Scholar, Sage, Scopus, Wiley Online, and Web of Science databases. The reference lists of credible articles were also searched to explore related studies. A total of 48 articles were initially selected, which was reduced to the final shortlist of 31 after removing duplicate papers and papers with only the abstract available.

In the second stage, the complete texts were scanned and each article was checked against brief inclusion and exclusion criteria presented in Table 1.

TABLE 1

Inclusion and exclusion criteria 


\begin{tabular}{|c|c|c|}
\hline & Inclusion Criteria & Exclusion Criteria \\
\hline Language & - English Language & Language other than English \\
\hline $\begin{array}{l}\text { Sources of } \\
\text { Data }\end{array}$ & $\begin{array}{l}\text { Journals on attitudes of the university } \\
\text { members towards accepting students with } \\
\text { ID } \\
\text { - Academic peer-reviewed journals attitudes } \\
\text { of the university members towards } \\
\text { accepting students with ID }\end{array}$ & $\begin{array}{l}\text { - Non-academic publications } \\
\text { - Scholarly articles on topics other than } \\
\text { attitudes of the university members towards } \\
\text { accepting students with ID }\end{array}$ \\
\hline $\begin{array}{l}\text { Types of } \\
\text { Studies }\end{array}$ & $\begin{array}{l}\text { - Studies involving qualitative or quantitative } \\
\text { methodology } \\
\text { - Detailed systematic reviews or meta- } \\
\text { analysis } \\
\text { - Studies based on thematic analysis or } \\
\text { interview analysis } \\
\text { - Authentic studies having credible } \\
\text { referencing }\end{array}$ & $\begin{array}{l}\text { Papers wherein credible references and } \\
\text { structure is absent } \\
\text { Online essays, theses, and blogs on molecular } \\
\text { markers }\end{array}$ \\
\hline $\begin{array}{l}\text { Websites } \\
\text { and } \\
\text { Databases }\end{array}$ & $\begin{array}{l}\text { - Wiley Online } \\
\text { - } \text { Google Scholar } \\
\text { - Sage } \\
\text { - Wcopus } \\
\text { Web of Science }\end{array}$ & $\begin{array}{l}\text { - Wikipedia } \\
\text { - Blogs } \\
\text { - Essay websites } \\
\text { - Educational dictionary } \\
\text { - Encyclopaedia }\end{array}$ \\
\hline $\begin{array}{l}\text { Time of } \\
\text { publication }\end{array}$ & $2010-2020$ & - $\quad<2010$ \\
\hline
\end{tabular}

After selecting the most relevant articles that met the inclusion criteria, the complete articles were retrieved and examined for quality assessment, which was conducted in the third stage of the search strategy. A total of 23 articles were available by the end of the second stage, which were subjected to the assessment criteria in Table 2:

TABLE 2

Assessment criteria 


\begin{tabular}{|l|l|}
\hline \multicolumn{1}{|c|}{ Quality Assessment Criteria } & \multicolumn{1}{c|}{ Assessment } \\
\hline Reliability & $\begin{array}{l}\text { High: A clear and precise description of the methodology used in the study for } \\
\text { the collection and analysis of the data, along with clearly interpreted findings } \\
\text { supported by credible evidence. }\end{array}$ \\
\cline { 1 - 1 } Credibility & $\begin{array}{l}\text { Medium: Substantial description of the research methods used for collection } \\
\text { and analysis and analysis of the data along with findings supported by } \\
\text { relevant evidence. }\end{array}$ \\
\cline { 1 - 2 } $\begin{array}{l}\text { Precise research question } \\
\text { the research objectives } \\
\text { research question(s) }\end{array}$ & $\begin{array}{l}\text { Low: Absence of description of the research methods and use of week } \\
\text { arguments and interpretations without effectively supported evidence. }\end{array}$ \\
\hline
\end{tabular}

Based on these criteria, articles whose methodology and data analysis were assessed as high and medium were selected for the final systematic review. At the end of the third stage of the search strategy, 12 articles were identified. The PRISMA framework is an evidence-based minimum set of items for reporting in systematic reviews and meta-analyses as in Figure 1 it explains the selection of the articles for the review in more detail.

\section{TABLE 3:}

Summary of the Articles 


\begin{tabular}{|c|c|c|c|c|}
\hline Author (s) & Article Title & Aim of the Study & Methodology & Main Findings \\
\hline $\begin{array}{l}\text { Forlin et al., } \\
(2011)\end{array}$ & $\begin{array}{l}\text { The Sentiments, } \\
\text { Attitudes, and } \\
\text { Concerns about } \\
\text { Inclusive } \\
\text { Education } \\
\text { Revised (SACIE- } \\
\text { R) Scale for } \\
\text { Measuring Pre- } \\
\text { Service } \\
\text { Teachers' } \\
\text { Perceptions } \\
\text { about Inclusion }\end{array}$ & $\begin{array}{lr}\text { To review } & \text { the } \\
\text { structure of the } & \text { ancIE scale and } \\
\text { undertake } & \text { an } \\
\text { assessment of its } \\
\text { suitability (for } \\
\text { various reasons) to } \\
\text { measure the } \\
\text { beliefs of teachers } \\
\text { regarding the } \\
\text { inclusion of } \\
\text { students with } \\
\text { disabilities. }\end{array}$ & $\begin{array}{l}\text { Survey with } 542 \text { pre- } \\
\text { service teachers from } \\
9 \text { institutions from } 4 \\
\text { countries (India, } \\
\text { Canada, Hong Kong, } \\
\text { and the United } \\
\text { States). }\end{array}$ & $\begin{array}{l}\text { The findings highlight that } \\
\text { the SACIE-R scale will be } \\
\text { helpful in providing useful } \\
\text { information to assist } \\
\text { universities and colleges in } \\
\text { preparing training to } \\
\text { address the needs of the } \\
\text { pre-service teachers to } \\
\text { work with diverse student } \\
\text { populations. }\end{array}$ \\
\hline $\begin{array}{l}\text { Leyser et al. } \\
(2011)\end{array}$ & $\begin{array}{l}\text { Students } \\
\text { with Disabilities } \\
\text { In Teacher } \\
\text { Education: } \\
\text { Changes In } \\
\text { Faculty Attitudes } \\
\text { Toward } \\
\text { Accommodations } \\
\text { Over Ten Years }\end{array}$ & $\begin{array}{lr}\text { To examine } & \text { the } \\
\text { changes in the } \\
\text { knowledge, } \\
\text { attitudes and } \\
\text { willingness to } \\
\text { accommodate the } \\
\text { students with } \\
\text { disabilities in } \\
\text { higher education. }\end{array}$ & $\begin{array}{lr}\text { A } & \text { survey } \\
\text { questionnaire was } \\
\text { conducted with the } \\
\text { faculty. }\end{array}$ & $\begin{array}{l}\text { The findings revealed there } \\
\text { is no difference in the } \\
\text { willingness of the faculty in } \\
\text { providing technological, } \\
\text { instructional, and testing } \\
\text { adaptations. However, it } \\
\text { was determined that the } \\
\text { faculty was more stringent } \\
\text { in its admission } \\
\text { requirements. }\end{array}$ \\
\hline $\begin{array}{l}\text { Costello and } \\
\text { Boyle (2013) }\end{array}$ & $\begin{array}{l}\text { Pre-service } \\
\text { Secondary } \\
\text { Teachers' } \\
\text { Attitudes } \\
\text { Towards } \\
\text { Inclusive } \\
\text { Education }\end{array}$ & $\begin{array}{l}\text { To examine the } \\
\text { attitudes of pre- } \\
\text { service secondary } \\
\text { teachers towards } \\
\text { inclusive education } \\
\text { in Australian } \\
\text { universities. }\end{array}$ & $\begin{array}{l}\text { A survey was } \\
\text { conducted with } 193 \\
\text { pre-service teachers } \\
\text { enrolled in courses } \\
\text { for secondary } \\
\text { education at an } \\
\text { Australian university. }\end{array}$ & $\begin{array}{l}\text { The findings reveal that } \\
\text { pre-service secondary } \\
\text { teachers had a positive } \\
\text { attitude towards inclusive } \\
\text { education. However, a } \\
\text { significant decline was } \\
\text { identified their positive } \\
\text { attitude over time. The } \\
\text { teachers for post- } \\
\text { graduation courses were } \\
\text { found to be more inclusive } \\
\text { than those for under- } \\
\text { graduation courses. }\end{array}$ \\
\hline $\begin{array}{l}\text { Griffin et al. } \\
(2012)\end{array}$ & $\begin{array}{l}\text { Attitudes } \\
\text { Toward } \\
\text { Including } \\
\text { Students with } \\
\text { Intellectual } \\
\begin{array}{l}\text { Disabilities at } \\
\text { College }\end{array}\end{array}$ & $\begin{array}{l}\text { To examine the } \\
\text { attitudes of college } \\
\text { students towards } \\
\text { the inclusion of } \\
\text { students with ID in } \\
\text { their classes. }\end{array}$ & $\begin{array}{lcc}\text { A survey } & \text { was } \\
\text { conducted with } & 256 \\
\text { college students. } & \end{array}$ & $\begin{array}{l}\text { The findings reveal that the } \\
\text { attitude of the students was } \\
\text { generally positive towards } \\
\text { the inclusion of the students } \\
\text { with ID. The findings also } \\
\text { highlight the social } \\
\text { acceptability of incisive } \\
\text { post-secondary education. }\end{array}$ \\
\hline $\begin{array}{l}\text { Lane and } \\
\text { Nagchoudhuri } \\
(2015)\end{array}$ & $\begin{array}{lr}\text { Teachers' } \\
\text { attitudes } \\
\text { towards } \\
\text { students } \\
\text { disability } \\
\text { higher } \\
\text { education. }\end{array}$ & $\begin{array}{l}\text { The purpose of this } \\
\text { paper is to explore } \\
\text { the attitudes of the } \\
\text { teachers towards } \\
\text { students with } \\
\text { disabilities in } \\
\text { higher education to } \\
\text { assess how well }\end{array}$ & $\begin{array}{lr}\text { The data } & \text { was } \\
\text { gathered } & \text { from } \\
\text { interviews } & \text { with } \\
\text { faculty } & \text { and } \\
\text { administrative } & \text { staff } \\
\text { along with a } & \text { web } \\
\text { survey with } & 500 \\
\text { students from } & 8\end{array}$ & $\begin{array}{l}\text { The findings emphasise that } \\
\text { it is important to equip } \\
\text { teachers with the best } \\
\text { information, resources, and } \\
\text { pedagogical skills to } \\
\text { address the needs of the } \\
\text { students with disabilities. }\end{array}$ \\
\hline
\end{tabular}




\begin{tabular}{|c|c|c|c|c|}
\hline & & $\begin{array}{l}\text { their teachers are } \\
\text { able to meet their } \\
\text { needs. }\end{array}$ & $\begin{array}{lr}\text { universities } & \text { in } 8 \\
\text { countries } & \text { (India, } \\
\text { Italy, } & \text { Belgium, } \\
\text { Germany, } & \text { Portugal, } \\
\text { Denmark } & \text { Sweden, } \\
\text { and Poland). } & \end{array}$ & \\
\hline $\begin{array}{l}\text { Cambbell, } \\
\text { Gilmore, and } \\
\text { Cuskelly } \\
(2014)\end{array}$ & $\begin{array}{l}\text { Changing } \\
\text { Student } \\
\text { Teachers } \\
\text { Attitudes } \\
\text { Towards } \\
\text { Disability and } \\
\text { Inclusion }\end{array}$ & $\begin{array}{l}\text { To examine the } \\
\text { attitude of the } \\
\text { teachers towards } \\
\text { disability } \\
\text { inclusion }\end{array}$ & $\begin{array}{l}\text { A survey was } \\
\text { conducted with } 274 \\
\text { pre-service teachers } \\
\text { at the beginning and } \\
\text { end of a semester }\end{array}$ & $\begin{array}{l}\text { The findings highlight that } \\
\text { combining information- } \\
\text { based instruction with } \\
\text { structured fieldwork is } \\
\text { effective in changing the } \\
\text { attitudes towards inclusion } \\
\text { and disability. }\end{array}$ \\
\hline $\begin{array}{l}\text { Zhang et al. } \\
(2018)\end{array}$ & $\begin{array}{l}\text { Inclusive higher } \\
\text { education for } \\
\text { students with } \\
\text { disabilities in } \\
\text { China: What do } \\
\text { the University } \\
\text { teachers think? }\end{array}$ & $\begin{array}{l}\text { To examine the } \\
\text { attitudes of the } \\
\text { teachers towards } \\
\text { the students with } \\
\text { disabilities } \\
\text { regarding their } \\
\text { inclusion } \\
\text { universities }\end{array}$ & $\begin{array}{l}\text { A } \\
\text { questionnaire was } \\
\text { used to explore the } \\
\text { overall perspective of } \\
\text { the university } \\
\text { teachers in China } \\
\text { regarding inclusive } \\
\text { higher education in } \\
\text { China. }\end{array}$ & $\begin{array}{l}\text { The findings reveal that } \\
\text { effective implementation of } \\
\text { inclusive higher education } \\
\text { should be supported } \\
\text { through an effective service } \\
\text { centre for students with } \\
\text { disabilities along with a } \\
\text { support network of } \\
\text { professionals and an } \\
\text { administrating support } \\
\text { system for students and } \\
\text { teachers. }\end{array}$ \\
\hline $\begin{array}{l}\text { Fossey et al., } \\
(2017)\end{array}$ & \begin{tabular}{lr}
\multicolumn{2}{l}{ Supporting } \\
students & with \\
mental health \\
issues & and \\
acquired brain \\
injury: \\
University \\
teaching staff \\
perspectives
\end{tabular} & $\begin{array}{l}\text { To examine the } \\
\text { perspectives and } \\
\text { actions of teaching } \\
\text { staff from one } \\
\text { university towards } \\
\text { students } \\
\text { mental with } \\
\text { issues or brain } \\
\text { injury }\end{array}$ & $\begin{array}{l}\text { An online survey was } \\
\text { undertaken } \\
\text { supplemented by } \\
\text { semi-structured } \\
\text { interviews for } \\
\text { investigating the } \\
\text { views and actions of } \\
\text { the teaching staff for } \\
\text { two student groups: } \\
\text { Students with mental } \\
\text { health concerns and } \\
\text { those who have } \\
\text { acquired brain injury }\end{array}$ & $\begin{array}{l}\text { The findings of this } \\
\text { research highlight the need } \\
\text { for improved staff training } \\
\text { and to manage other } \\
\begin{array}{l}\text { institutional forces } \\
\text { associated with the } \\
\text { universities. }\end{array}\end{array}$ \\
\hline $\begin{array}{l}\text { Phillips, } \\
\text { Fortney, and } \\
\text { Swafford } \\
\text { (2019). }\end{array}$ & $\begin{array}{l}\text { College } \\
\text { students' social } \\
\text { perceptions } \\
\text { towards } \\
\text { individuals with } \\
\text { intellectual } \\
\text { disability. }\end{array}$ & $\begin{array}{l}\text { To discuss the } \\
\text { social perceptions } \\
\text { of American } \\
\text { college students } \\
\text { towards the } \\
\text { students with ID, } \\
\text { factors influencing } \\
\text { social perception } \\
\text { and determine } \\
\text { whether the level } \\
\text { of functioning } \\
\text { influences the } \\
\text { perception of an } \\
\text { individual. }\end{array}$ & $\begin{array}{l}\text { The data for the } \\
\text { study was gathered } \\
\text { from } 186 \text { American } \\
\text { college students }\end{array}$ & $\begin{array}{l}\text { The findings reveal an } \\
\text { overall positive perception } \\
\text { towards students with ID } \\
\text { among the students having } \\
\text { a higher knowledge of } \\
\text { intellectual disability. The } \\
\text { paper also helped in } \\
\text { determining the factors that } \\
\text { require more attention in } \\
\text { educational programs and } \\
\text { awareness campaigns. }\end{array}$ \\
\hline Alqazlan, & Post-secondary & synthesise & systematic & The findings of this study \\
\hline
\end{tabular}




\begin{tabular}{|c|c|c|c|c|}
\hline $\begin{array}{l}\text { Alallawi, and } \\
\text { Totsika } \\
\text { (2019) }\end{array}$ & $\begin{array}{l}\text { education for } \\
\text { young people } \\
\text { with intellectual } \\
\text { disabilities: A } \\
\text { systematic } \\
\text { review of } \\
\text { stakeholders' } \\
\text { experiences }\end{array}$ & $\begin{array}{l}\text { evidence on the } \\
\text { experiences of } \\
\text { post-secondary } \\
\text { education in } \\
\text { respect of the } \\
\text { students with ID. }\end{array}$ & $\begin{array}{l}\text { review was } \\
\text { conducted through } 22 \\
\text { studies to investigate } \\
\text { the PSE for students } \\
\text { with ID. }\end{array}$ & $\begin{array}{l}\text { reveal that positive } \\
\text { experiences of PSE can be } \\
\text { attributed to the increased } \\
\text { social skills and } \\
\text { independence of students } \\
\text { with ID. Findings also } \\
\text { confirm that inclusive PSE } \\
\text { is related to more positive } \\
\text { experiences for the } \\
\text { stakeholder groups. }\end{array}$ \\
\hline $\begin{array}{l}\text { Alnahdi, } \\
\text { Elhadi, and } \\
\text { Schwab } \\
(2020) \text {. }\end{array}$ & $\begin{array}{lr}\text { The positive } \\
\text { impact } & \text { of } \\
\text { knowledge and } \\
\text { quality } & \text { of } \\
\text { contact } & \text { on } \\
\text { university } & \\
\text { students' } \\
\text { attitudes } \\
\text { towards people } \\
\text { with intellectual } \\
\text { disability in the } \\
\text { Arab world }\end{array}$ & $\begin{array}{l}\text { To examine the } \\
\text { attitudes of the } \\
\text { undergraduate } \\
\text { students towards } \\
\text { people with ID in } \\
\text { respect of their } \\
\text { frequency of } \\
\text { interacting with } \\
\text { them, the quality of } \\
\text { such contact, and } \\
\text { their knowledge of } \\
\text { ID. }\end{array}$ & $\begin{array}{l}\text { The survey was } \\
\text { conducted through a } \\
\text { sample gathered } \\
\text { from } \quad 1001 \\
\text { undergraduate } \\
\text { students consisting of } \\
458 \text { male students } \\
\text { and } 543 \quad \text { female } \\
\text { students from Saudi } \\
\text { Arabia and Egypt. }\end{array}$ & $\begin{array}{l}\text { From the findings of the } \\
\text { research, it is revealed that } \\
\text { there is no difference } \\
\text { between the participants } \\
\text { from the two countries. This } \\
\text { confirms that high quality } \\
\text { contact is a major predictor } \\
\text { of the attitudes of the } \\
\text { students. Hence, it is } \\
\text { important to improve such } \\
\text { contexts significantly. }\end{array}$ \\
\hline Wintle (2015) & $\begin{array}{l}\text { Preparing } \\
\text { students with } \\
\text { intellectual } \\
\text { disabilities to } \\
\text { audit inclusive } \\
\text { university } \\
\text { courses }\end{array}$ & $\begin{array}{l}\text { To examine the } \\
\text { steps undertaken } \\
\text { by the IPSE } \\
\text { preparation } \\
\text { program to prepare } \\
\text { students with ID } \\
\text { disabilities for } \\
\text { auditing classes. }\end{array}$ & $\begin{array}{l}\text { Data was gathered } \\
\text { from } 13 \text { CLAC prep } \\
\text { students. }\end{array}$ & $\begin{array}{l}\text { The findings highlight the } \\
\text { need for increased inclusion } \\
\text { of students with ID in } \\
\text { education classes. }\end{array}$ \\
\hline
\end{tabular}

\section{Results And Discussion}

For the analysis, the following key themes were employed: participant profile, current practice, university goals for accepting students with ID, university requirements for accepting students with ID, comparison of the status of students with ID, and attitudes of the university members towards accepting students with ID. To address the research question, which focuses on the attitudes of university members towards accepting students with ID, the selected articles were analysed and discussed in terms of the identified themes.

\section{Subject}

Three of the twelve studies examined for this review focused on determining the attitudes of teachers towards the acceptance of students with ID. In particular, changes in the attitudes of teachers towards students with disabilities and attitudes towards the inclusion of students with ID at colleges were examined (Leyser et al., 2011; Griffin et al., 2012; Lane and Nagchoudhuri, 2015). Five of the nine studies focused on inclusive education, with an emphasis on students with disabilities. These included pre- 
service teachers' perceptions of inclusion and their attitudes towards inclusive education, disability and inclusion, and inclusive higher education (Forlin et al., 2011; Costello and Boyle, 2013; Cambbell, Gilmore, and Cuskelly, 2014; Zhang et al., 2018; Wintle, 2015). Two studies focused on the perspectives of university staff members towards students with ID (Fossey et al., 2017; Alqazlan, Alallawi, and Totsika, 2019), and two examined the perceptions of university students towards students with ID (Phillips, Fortney, and Swafford 2019; Alnahdi, Elhadi, and Schwab, 2020). All of the studies focused on and presented elaborate discussions on the acceptance of students with ID, as shown in Fig. 2

\section{Participant Profile}

Out of the eight studies, the participant profiles in two focused on faculty and administrative staff, two focused on pre-service teachers in secondary education, and two focused on university lecturers. One study used service teachers and three studies used college students as participants to gather data (See Fig. 2). A study by Alqazlan, Alallawi, and Totsika (2019) did not use any participants and conducted a systematic review of 22 articles. One study also used prep students with ID as participants. The findings indicate that the majority of studies used teachers as participants, while only one study took responses from college students.

\section{Current Practices}

Of the eight examined studies, two focused on promoting the education of students with disabilities through reforms and facilities, two focused on the incorporation of disability support services and necessary assistance, and one focused on increasing the confidence of students. The right to education, teacher training, and inclusive education were each examined by two studies, as shown in Fig. 3. According to Lane and Nagchoudhur (2015), the teaching and non-teaching staff at universities play a major role in increasing the confidence of students with disabilities. Educational institutes and universities are important components of the Universal Declaration of Human Rights, which the aim of ensuring and promoting the education of students with disabilities. In addition, the Convention on the Rights of Persons with Disabilities also encourages disabled students by providing them with the right to education. The implementation of these governmental policies has increased the enrolment of students with disabilities and provided them with accommodating and other necessary equipment (Lane and Nagchoudhur, 2015). Alqazlan, Alallawi, and Totsika (2019) also explain that students with ID have the right to access colleges and universities; hence, these universities focus on inclusive education programs for the students with ID. The literature also revealed that universities focus on inclusive education through individualised services including technology training, tutoring, and educational coaching, which are specifically designed using models for students with ID (Alqazlan, Alallawi, and Totsika, 2019). However, Campbell, Gilmore, and Cuskelly (2014) state that universities must focus on providing appropriate training for teaching staff and increasing their knowledge and skills. Hence, teachers can understand the needs of students and boost their confidence. The implementation of these training sessions has positively affected the attitude of teachers and university staff towards students with disabilities and improved communication between students and staff (Campbell, Gilmore and Cuskelly, 2014). 
The study by Zhang et al. (2010) revealed that universities have actively taken responsibility for helping students with disabilities. Further, they have developed disability support services (DSS) offices that can assist in the provision of adequate and timely information for staff regarding the needs of students with disabilities. These support services have helped and encouraged students with disabilities to excel in their chosen fields by developing a sense of responsibility in the minds of the university staff (Zhang et al., 2010). Costello and Boyle (2013) stated that most countries and universities are willing to make the necessary reforms in their educational standards and policies, with the intention of providing special facilities for students with disabilities (including educational and healthcare facilities at the university level). The universities and colleges understand the importance and role of the right to education; therefore, they are committed to promoting the inclusion of disabled students in their programmes and prohibiting any form of discrimination against students with ID (Costello and Boyle, 2013).

In addition, Leyser et al. (2011) stated there are various political and economic factors that have increased the proportion of students with disabilities in higher educational institutions. Most universities have succeeded in establishing an adequate environment that enables them to access online lectures and provides necessary assistance for exam preparation. These basic accommodation facilities have helped students to understand their subject content and have motivated them to perform better and achieve good scores (Leyser et al., 2011). Kuyini and Mangope (2011) stated that government-sponsored training and special education courses, which help teachers attain sufficient knowledge about the various types of disabilities and problems faced by disabled students, can improve the overall teaching-learning experience. Moreover, universities and colleges have been further encouraged to make the necessary changes in their educational systems by implementing the principle of inclusive education (Kuyini and Mangope, 2011).

\section{University Goals to Accept Students with ID}

Two studies highlighted good education facilities (Lane and Nagchoudhur, 2015; Leyser et al. (2011) as a university goal for accepting students with disabilities, while each of the following were the focuses in one study: good social and education lifestyle (Griffin et al., 2012); basic facilities and services for students with disabilities (Zhang et al., 2010), and providing equal education for the students (Costello and Boyle, 2013). One study examined the increasing educational programs and awareness campaign (Phillips, Fortney and Swafford, 2019). These findings indicate that the majority of studies focused on the previously identified goals towards accepting students with ID.

According to Lane and Nagchoudhur (2015), students with disabilities are not provided with the opportunity of receiving appropriate education, which increases their unemployment rate. Therefore, universities should aim to provide good educational facilities for students with disabilities to ensure they can access adequate employment opportunities in the future (Lane and Nagchoudhur, 2015). In addition, Griffin et al. (2012) stated that awareness of the importance of post-secondary education is increasing among students with disabilities. Moreover, universities are actively participating in providing higher education to students with ID to ensure they can achieve a good social and economic lifestyle in the 
future (Griffin et al., 2012). Phillips, Fortney and Swafford (2019) highlighted the need for increased educational programs and awareness campaigns for students with ID, which would be helpful in targeting the prevailing stereotypes, discomfort, tenderness, and knowledge of rights and capacity. In a similar context, Zhang et al. (2010) stated that universities are trying to ensure that staff members understand the basic needs of students with ID. Further, they are working towards designing appropriate department-level administrative policies and activities that provide basic facilities and services for students with disabilities (Zhang et al., 2010).

According to Costello and Boyle (2013), the major university goals are to accommodate and provide good educational services to all types of students, irrespective of any disabilities. These goals help in providing equal education for students and in the overall social development of society wherein all students have equal opportunities and rights (Costello and Boyle, 2013). Similarly, Leyser et al. (2011) reported that the increasing number of students with disabilities in the United States and the United Kingdom has increased the role of educational institutes in providing educational facilities. The universities tend to provide equal education opportunities with the help of technology and computers, which renders the learning process easy and accessible (Leyser et al., 2011). These findings are further supported by the views of Kuyini and Mangope (2011) who note universities aim to provide good quality education for students with disabilities by providing staff training with the help of Postgraduate Diploma in Education (PGDE) programs. These programs increase the skill-levels of teachers when dealing with students with disabilities in higher education. Further, these sessions boost the confidence of teachers by developing a special bond with students with ID and help in creating a positive environment in the university campus (Kuyini and Mangope, 2011).

\section{University Requirements for Accepting Students with ID}

Three studies from the examined papers focused on adequate training for staff members (Lane and Nagchoudhur, 2015; Costello and Boyle, 2013; Zhang et al., 2018), which is an important university requirement for accepting students with ID. Three studies focused on positive attitudes towards the students with ID (Lane and Nagchoudhur, 2015; Campbell, Gilmore and Cuskelly, 2014; Forlin et al., 2011), while another three identified inclusive policies as an important requirement (Campbell, Gilmore, and Cuskelly, 2014; Costello and Boyle, 2013; Zhang et al., 2018). One study focused on self-expression and self-awareness as key focuses (Wintle, 2015) (See Fig. 5)

Lane and Nagchoudhur (2015) stated it is very important for universities to provide adequate training for their staff to ensure they can develop positive attitudes towards students with disabilities and interact with them appropriately (Lane and Nagchoudhur, 2015). In addition, Campbell, Gilmore, and Cuskelly (2014) suggested that universities should create a positive attitude towards students with disabilities among staff members by increasing their knowledge of disabilities and appropriate modes of interacting with people with disabilities. This would enable the universities to implement inclusive policies to support and encourage the students effectively (Campbell, Gilmore, and Cuskelly, 2014). Costello and Boyle (2013) are also of the view that there is a need for proper training of teachers to increase their knowledge 
of the importance of inclusive education. Appropriate training of teachers contributes to the effective implementation of inclusive education policies (Costello and Boyle, 2013).

Forlin et al. (2011) stated that training teachers and other university staff members according to the needs of the disabled students was not sufficient, because universities require a special curriculum that helps cover the major aspects of providing education to disabled students. The practical implementation of training for teachers to support and encourage disabled students requires the development of detailed courses that can help fulfil the educational and accommodation needs of students with disabilities by creating a good level of understanding between them and the teachers (Forlin et al., 2011). Accordingly, it was determined that the development of appropriate training modules for teachers and other staff members and relevant courses of study are the two major requirements for universities to support students with ID. Zhang et al. (2018) proposed that universities should provide accommodating facilities (such as straightforward exam forms and feasible protocols) to implement inclusive education more effectively (Zhang et al., 2018). Phillips, Fortney, and Swafford (2019) do not explain any specific requirements undertaken by the university for the acceptance of the students with disabilities. However, Wintle (2015) revealed that some universities focused on familiarising prep students with the university to ensure they were comfortable at the campus and happy with life at the campus. They also offered opportunities to promote self-awareness among students with ID through role playing, class discussions, and self-expression to promote participation of the students (Wintle, 2015).

\section{Comparison of Status of Students with ID}

Two studies highlighted positive attitudes towards accepting students with ID in universities in the United States and the United Kingdom (Campbell, Gilmore, and Cuskelly, 2014; Griffin et al., 2012), while another two studies highlighted inclusive educational policies (Leyser et al., 2011). One study focused on examining equal educational opportunities (Leyser et al., 2011) in US and UK universities. One study focused on increased interaction between students with and without disabilities in US universities (Phillips, Fortney, and Swafford, 2019) (See Fig. 6). According to the results of a study by Campbell, Gilmore, and Cuskelly (2014), the presence of a positive attitude towards the inclusion of students with Down syndrome has been noticed among the students and teachers in the UK. Further, the provision of appropriate staff training has significantly helped in shaping a positive attitude towards the students with disabilities (Campbell, Gilmore, and Cuskelly, 2014). Griffin et al. (2012) stated that a positive attitude towards students with ID was also observed among students studying in US universities. It was also noted that teachers and other students willingly communicate and interact with students with disabilities and help them to participate in university programmes (Griffın et al., 2012).

Leyser et al. (2011) stated there has been a significant increase in the enrolment of students with disabilities at UK and US universities, implying these countries follow inclusive educational policies and promote the principle of equal educational opportunities for all students by promoting their admission. The implementation of the American Disability Act (ADA) has helped in removing the social barriers to inclusive education and provided equal access to education for all students (Leyser et al., 2011). Phillips, 
Fortney, and Swafford (2019) confirmed these findings. They further stated that due to changes in legislation and social perspectives in the United States, increased inclusion and an increase in the frequency of interactions between students and students with ID had been noted. Moreover, this increasing trend is continuing. (Phillips, Fortney, and Swafford, 2019).

\section{Attitudes of the University Members Toward Accepting Students with ID}

One study focused on the lack of proper knowledge about the rights of students with disabilities (Lane and Nagchoudhur, 2015), while another focused on an unwillingness to support and encourage students with disabilities (Lane and Nagchoudhur, 2015), which signalled an attitude of unacceptance. One study focused on inadequate attitudes towards students with disabilities (Campbell, Gilmore and Cuskelly, 2014), while another highlighted the fact that staff face many challenges in providing accommodating facilities for students with disabilities (Zhang et al., 2018). Six studies focused on positive attitudes towards students with disabilities (Costello and Boyle, 2013; Leyser et al., 2011; Fossey et al., 2017; Alqazlan, Alallawi, and Totsika, 2019; Alnahdi, Elhadi, and Schwab, 2020; Phillips, Fortney, and Swafford, 2019), while one focused on the willingness of teachers to participate in the education of students with disabilities (Leyser et al., 2011). One study also highlighted the neutral attitude of students towards students with ID (Alnahdi, Elhadi, and Schwab, 2020), as shown in Fig. 7.

According to Lane and Nagchoudhur (2015), almost $50 \%$ of teaching and other staff at universities do not have correct knowledge about the rights of students with disabilities, which adversely affects their attitude towards these students. Further, teachers are not adequately trained and find it difficult to deal with students with disabilities. Moreover, teachers can be unwilling to support and encourage students with disabilities, highlighting a negative attitude among university staff (Lane and Nagchoudhur, 2015). Conversely, Campbell, Gilmore, and Cuskelly (2014) stated that while teachers mostly accept students with mild disabilities in the United States, their attitude towards students with major disabilities is poor and they refrain from admitting such students to their universities. This negative and non-encouraging attitude of teachers negatively affects the overall expectations and morale of students with disabilities, affecting their retention rate in university programmes (Campbell, Gilmore, and Cuskelly, 2014). Alnahdi, Elhadi, and Schwab (2020) reveal that the attitudes of university students from Saudi Arabia and Egypt were mostly neutral regarding students with ID. Moreover, while the attitude of pre-service teachers was found to be positive towards inclusive schooling, they were less positive regarding the daily practices of teachers or their involvement in the programs for inclusive education. The literature also highlighted the need for a closer, more meaningful, and personal contact to help overcome prejudices towards students with ID (Alnahdi, Elhadi, and Schwab, 2020).

Zhang et al. (2010) stated that university faculties and other staff face many challenges in providing accommodating facilities for students with disabilities, relying on disability service institutions for information. However, many staff members have a positive attitude towards students with disabilities and believe that their inclusion in university programmes increases the overall diversity level (Zhang et al., 2010). Similarly, Costello and Boyle (2013) found that teachers play a major role in developing a healthy 
and encouraging environment for students. The majority of teaching and other university staff have a positive attitude towards the education of students with disabilities. Moreover, it was identified that appropriate teacher training positively affects their behaviour towards the inclusion of students with disabilities in an educational setting. The presence of a positive attitude among teachers motivates the students and helps in the implementation of effective inclusive strategies (Costello and Boyle, 2013).

Similarly, Leyser et al. (2011) revealed a considerable change in the behaviour of teachers and other university staff in providing basic accommodating facilities for students with disabilities, willingly participating in their education and engaging in regular communication with them. The application of special education programs and seminars also increases the willingness of university staff towards the implementation of inclusive education. Moreover, the positive change in the attitude of teachers over the last decade has resulted in an increase in the number of admissions of students with disabilities in the educational environment (Leyser et al., 2011). Kuyini and Mangope (2011) discovered that the attitudes of teachers and students towards inclusive educational policies and students with disabilities depended on many factors. These included confidence levels, teaching experience of the faculties, and knowledge about different laws and regulations. These factors primarily define the attitudes of staff members in universities. Mostly, staff members in universities are not satisfied with the implementation of inclusive education policies that adversely affect the quality of student-teacher interactions and decrease the confidence levels of students with disabilities. This dissatisfaction manifested as negative attitudes in the form of anger and frustration when dealing with students with disabilities, which was discouraging for the students (Kuyini and Mangope, 2011). Phillips, Fortney, and Swafford (2019) revealed that the overall attitudes of students towards students with ID were positive. Such positive perceptions offer hope for supporting the relevant inclusions and standards of fair play for individuals with ID and ensures greater support compared to previous generations (Phillips, Fortney, and Swafford, 2019). The study by Alqazlan, Alallawi, and Totsika (2019) stated that the majority of stakeholder groups participating in programmes that focus on post-graduation education of people with disabilities had a positive attitude regarding their experience and were very happy with their interactions. It was also claimed that postgraduation education helped students with ID to improve their skills in participation, making notes, and studying (Alqazlan, Alallawi, and Totsika, 2019).

According to Zhang et al. (2018), inclusive education faces a significant number of challenges, with one of the most common being attitudes of the community and teachers that hamper the growth of inclusive education. It was identified that while teachers and students relate emotionally to students with disabilities, they do not want to accept them as part of the university. This highlights a negative attitude of some university staff and students towards students with disabilities (Zhang et al., 2018). Conversely, Fossey et al. (2017) found that teachers show a positive attitude towards students with mental illnesses and disabilities. They posited that regular communication, good service, and accommodating environments boosted the confidence level of students and helped to develop a good environment at the university campus (Fossey et al., 2017). 


\section{Conclusion}

Based on the overall findings of this paper, it can be stated that universities conducting training sessions for teaching and other university staff has helped to create a positive impact on their attitudes towards students with disabilities. Further, this has helped to improve communication between the students and staff members. Some universities also use disability support services officers to ensure students with disabilities receive maximum assistance. These services continually encourage students with disabilities to excel in education. The findings also signify that universities acknowledge the importance of accepting students with disabilities and recognise their right to education; hence, they have committed themselves towards the well-being and inclusion of these students. Moreover, this has also motivated universities to provide equal opportunities for all students and to utilise technology to ensure accessible and suitable education for students with disabilities. Additionally, universities are undertaking training sessions for their teachers. This will allow them to develop pedagogy according to the needs of students with disabilities and a specific curriculum that helps to address their special requirements and enhance their skills. The findings also suggest that while teaching and other university staff tend to encounter substantial challenges in accepting students with ID and addressing their personal and educational requirements, there is a positive attitude regarding the acceptance of students with ID.

\section{Declarations}

\section{Funding}

The authors extend their appreciation to the Deanship of Scientific Research at Jouf University for funding this work through research grant no (DSR2020-06-3672) .

\section{Competing interests}

The authors declared no potential conflicts of interest with respect to the research, authorship, and/or publication of this article

\section{Availability of supporting data}

-The datasets used and/or analysed during the current study are available from the corresponding author on reasonable request.

-All data generated or analysed during this study are included in this published article.

\section{Authors' contributions}

Adel Al-Anzi is an assistant professor at Jouf University, Department of Special Education .My research interests are about students with intellectual disabilities and their transition to post-school I have 
published several articles focused on the employment of people with disabilities and the importance of their integration into society .Before that, I worked as a teacher for students with intellectual disability in the elementary stage for ten years in different cities in Saudi Arabia and I have many activities to facilitate their inclusion in the Saudi society, I am also a member of many associations and institutions that deal and provide assistance for people with disabilities in Saudi Arabia and the Arab world.

Ahmed Gadelmawla is an Assistant Professor of Special Education, Department of Special Education, Faculty of Education, Jouf University, he has published four books and twenty papers in the field of special education, 12 of which were in intellectual disability. He called for Arbitration to many researches in the field of intellectual disability, preparing and evaluating nearly 40 training programs for intellectually disabled students

Ethics approval (Not applicable)

Consent to participate ( Not applicable)

Consent for publication

I confirm that I have no objection to my research being published in Scientometrics

\section{Acknowledgements}

I would like to thank everyone who contributed to this work and provided us with assistance, especially our colleagues in the Department of Special Education and Jouf University.

\section{References}

1. Alnahdi, G. H., Elhadi, A., \& Schwab, S. 2020. The positive impact of knowledge and quality of contact on university students' attitudes towards people with intellectual disability in the Arab world. Research in Developmental Disabilities, pp. 1-7.

2. Alqazlan, S., Alallawi, B., \& Totsika, V. (2019). Post-secondary education for young people with intellectual disabilities: A systematic review of stakeholders' experiences. Educational Research Review, 28, 1-21.

3. Argyropoulos, V. 2019. Inclusion, Equity and Access for Individuals with Disabilities: Insights from Educators Across World. Springer Singapore.

4. Boland, A., Cherry, G., \& Dickson, R. 2017. Doing a Systematic Review: A Student's Guide. SAGE Publications.

5. Bouillet, D., \& Mirosevic, J. K. 2015. Students with disabilities and challenges in education practice. Croatian Journal of Education, pp. 11-26. 
6. Campbell, J., Gilmore, L., \& Cuskelly, M. (2014). Changing Student Teachers Attitudes Towards Disability and Inclusion. Journal of Intellectual \& Developmental Disability, 28(4), 369-379.

7. Costello, S., \& Boyle, C. (2013). Pre-service Secondary Teachers' Attitude Towards Inclusive Education. Australian Journal of Teacher Education, 38(4), 129-143.

8. Forlin, C., Earle, C., Loreman, T., \& Sharma, U. (2011). The Sentiments, Attitudes, and Concerns about Inclusive EducationRevised (SACIE-R) Scale for Measuring Pre-Service Teachers' Perceptions about Inclusion. Exceptionality Education International, 21, 50-65.

9. Fossey, E., Bigby, C., Chaffey, L., Mealings, M., Williams, A., Serry, T., et al. (2017). Supporting Students with Mental Health Issues and Acquired Brain Injury: University Teaching Staff Perspectives. Journal of the Australian and New Zealand Student Services Association, 25(1), 1-21.

10. Gibbons, M. M., Cihak, D. F., Mynatt, B., \& Wilhoit, B. E. (2015). Faculty and Student Attitudes Toward Postsecondary Education for Students with Intellectual Disabilities and Autism. Journal of Postsecondary Education and Disability, 28(2), 149-169.

11. Gough, D., Thomas, J., \& Oliver, S. 2017. An Introduction to Systematic Reviews. SAGE Publications.

12. Greene, B. L. 2017. Teachers' attitudes towards inclusive classrooms. [Online]. Available at: https://www.semanticscholar.org/paper/Teachers\%27-Attitudes-toward-Inclusive-ClassroomsGreene/d1c5db90ddc45d69c89aa22eb0d84601d839a35d. [Accessed on: 18 November 2020].

13. Griffin, M. M., Summer, A. H., McMillan, E. D., Day, T. L., \& Hodapp, R. M. (2012). Attitudes Toward Including Students With Intellectual Disabilities at College. Journal of Policy and Practice in Intellectual Disabilities, 9, 234-239.

14. Hayes, A. M., \& Bulat, J. 2017. Disabilities Inclusive Education Systems and Policies Guide for Lowand Middle-Income Countries. [Online]. Available at:

https://www.ncbi.nIm.nih.gov/books/NBK554622/. [Accessed on: 18 November 2020].

15. Kabuta, L. G. 2014. Problems facing students with physical disabilities in higher institutions in Tanzania. [Online]. Available at: https://core.ac.uk/download/pdf/33425411.pdf. [Accessed on 18 November 2020].

16. Kuyini, A. B., \& Mangope, B. (2011). Teachers' attitudes and concerns about inclusive education in Ghana and Botswana. International Journal of Whole Schooling, 7(1), 20-37.

17. Lane, L., \& Nagchoudhur, M. 2015. Teachers Attitudes toward Students with Disability in Higher Education. European Action on Disability in Higher Education (EADHE), pp. 1-11.

18. Leyser, Y., Greenberger, L., Sharoni, V., \& Vogel, G. (2011). Student with disabilities in teacher education: changes in faculty attitudes toward accommodations over ten years. International Journal of Special Education., 26, 162-174.

19. Obiozor, W. E., Onu, V. C., \& Ugwoegbu, I. (2010). Academic and social challenges facing students with Developmental and learning disabilities in higher institutions: Implications to African colleges and universities. African Journal of Teacher Education, 1(1), 126-140.

20. Phillips, A. B. P., Fortney, S., \& Swafford, L. (2019). College students' social perceptions towards individuals with intellectual disability. Journal of Disability Policy Studies, 30(1), 3-10. 
21. UNESDOC Digital Library. 2015. The Right to education for persons with disabilities. [Online]. Available at: https://unesdoc.unesco.org/ark:/48223/pf0000232592. [Accessed on: 18 November 2020].

22. Wintle, J. (2015). Preparing students with intellectual disabilities to audit inclusive university courses. British Journal of Special Education, 42(2), 183-192.

23. Zhang, D., Landmark, L., Reber, A., Hsu, H. Y., Kwok, O., \& Benz, M. (2010). University Faculty Knowledge, Beliefs, and Practices in Providing Reasonable Accommodations to Students with Disabilities. Remedial and Special Education, 31, 276-286.

24. Zhang, Y., Rosen, S., Cheng, L., \& Li, J. 2018. Inclusive Higher Education for Students with Disabilities in China: What Do the University Teachers Think? Higher Education Studies 8, pp. 104-115.

\section{Figures}



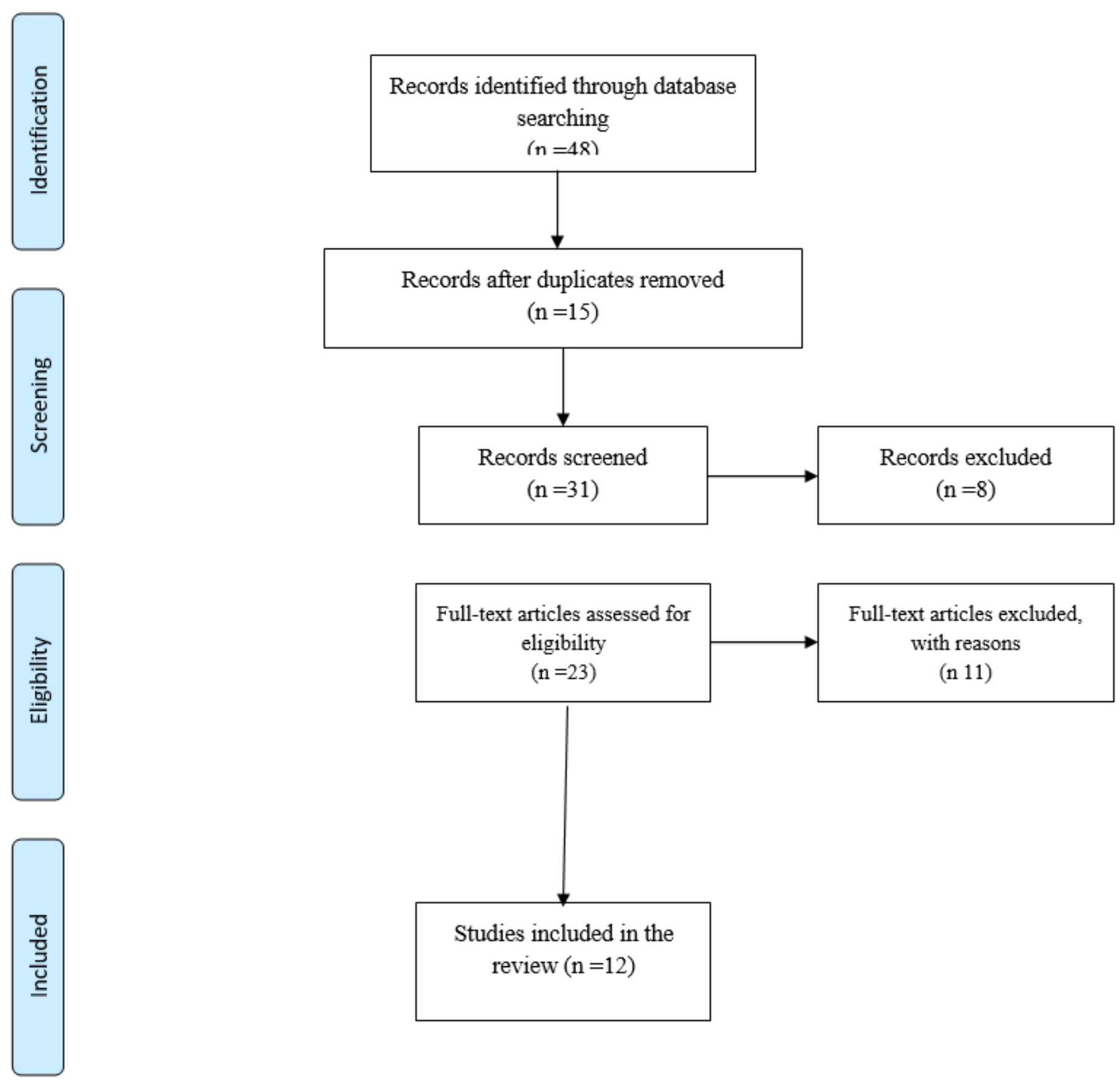

Figure 1

PRISMA framework 


\section{Subject}

Attitude of the teachers towatds acceptance of students with intellectual disabilities

E Inclusive education emphasising on the students with disabilities

Perspectives of the university staff members towards students with mental health issues

- Perceptions of the university students towards students with intellectual disabilities

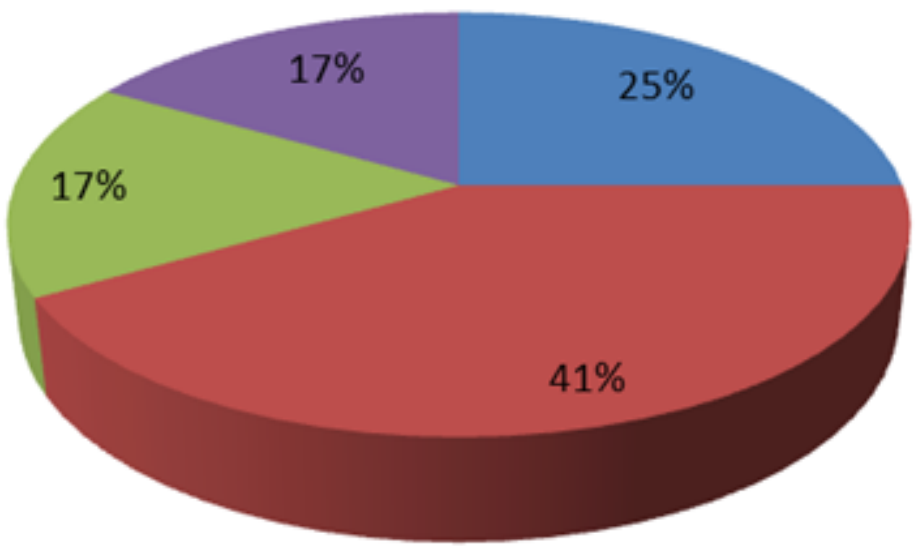

Figure 2

acceptance of students with ID 


\section{Participants}

- Service teachers

- Faculty and administrative staff

- Pre-service teachers in secondary education $n$ College students

n University teachers a Students with intellectual disabilities

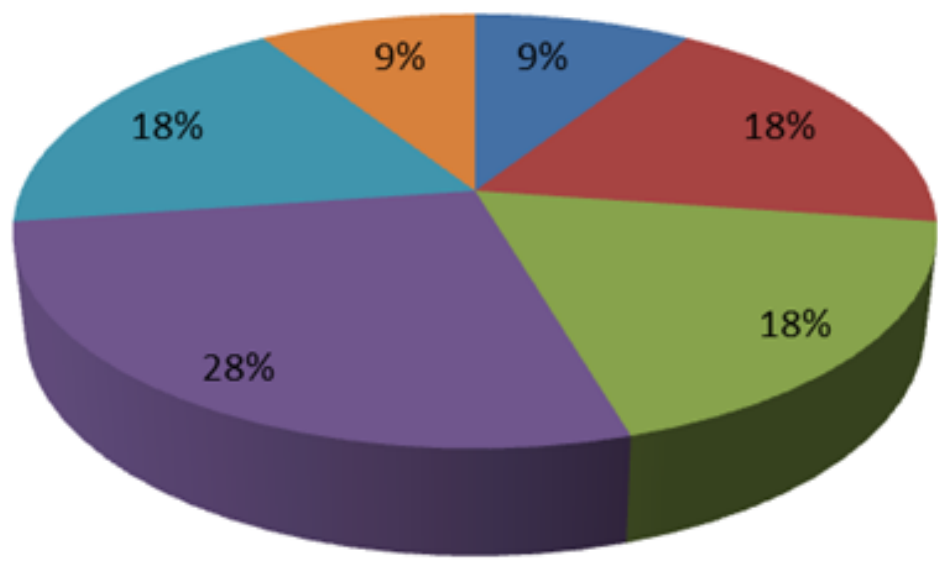

Figure 3

Participants 


\section{Current Practices}

Increasing confidence of the students

n Promoting eductaion of students with disabilities through reforms and facilities

Right to Education

- Training of teachers

- Incorporation of disabilty support services and necessary assistance

- Inclusive education

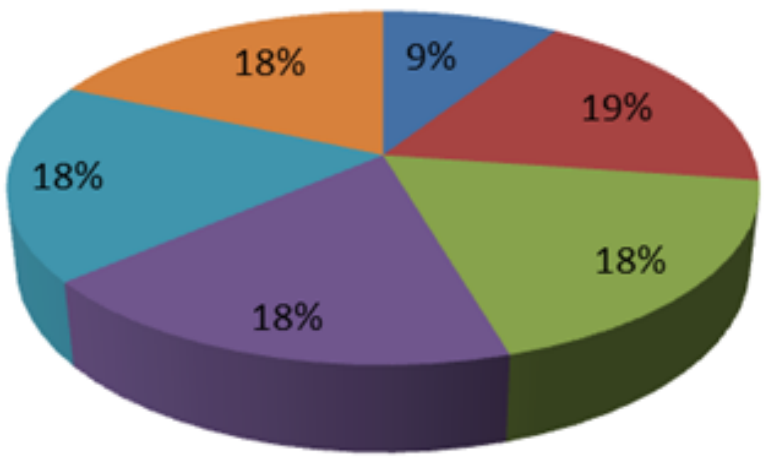

Figure 4

Current Practices 


\section{University goals to accept students with intellectual disabilities}

- Good educational facilities

n Good social and educational lifestyle

Basic faciliaties and services to the disabled students

access to equal education to the students

- Increasing educational programs and awareness campaigns

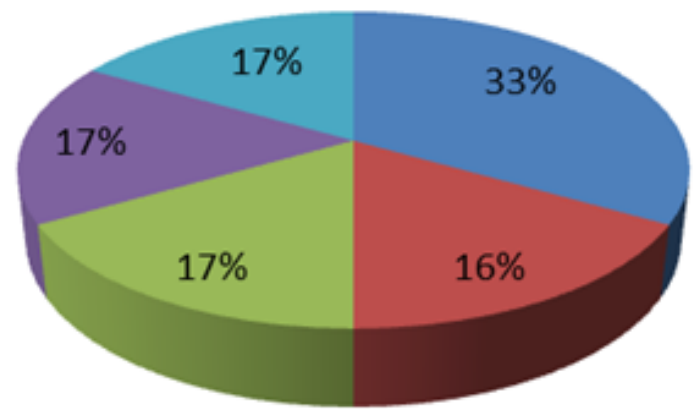

Figure 5

University goals to accepting students with intellectual disabilities 


\title{
University requirements to accept students with intellectual disabilities
}

\author{
E Adequate training to the staff members \\ n Positive attitudes towards the students with intellectual disabilities \\ - Inclusive policies \\ - Promoting self-awareness and self-expression
}

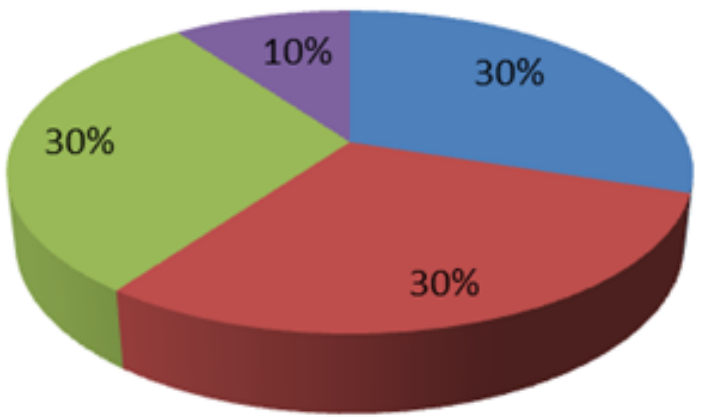

Figure 6

University requirements to accept students with intellectual disabilities 


\section{Comparison of the status of students with intellectual disabilities}

- Positive attitude towards accepting students with intellectual disabilities

n Inclusive educational policies

Equal educational opportunities

n Increased interaction between students with and without disabilities

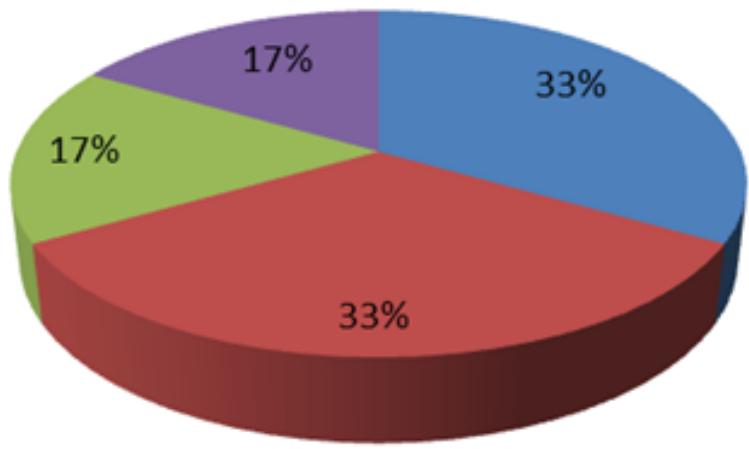

Figure 7

Comparison of the status of students with intellectual disabilities 


\section{Attitudes of the university members towards accepting students with intellectual disabilities}

n Lack of proper knowledge about the rights of students with a disability

n Low willingness to support and encourage students with a disability

n Inadequate attitude towards students with disabilities

- Challenges encountered by the staff

nositive attitude towards the students with disability

Willingness of the teachers to participate in the education of disabled students

neutral attitudes towards students with intellectual disabilities

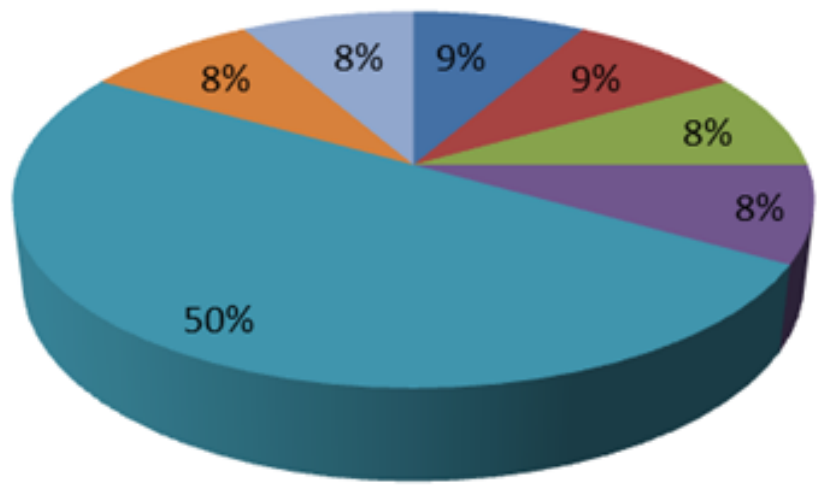

Figure 8

Attitudes of the University Members Toward Accepting Students with ID 